\title{
THE ENGLISH LETTERS BY DON MANUEL ÁLVAREZ ESPRIELLA, PSEUDO-TRANSLATED BY ROBERT SOUTHEY (1807)
}

\author{
JUAN MIGUEL ZARANDONA \\ Universidad de Valladolid
}

\begin{abstract}
The romantic English writer Robert Southey (1774-1843) was not only an experienced translator himself from early Castilian Spanish classics, but also a skilful manipulator of the sophisticated cultural processes involved in any translation sample. This is the case of his Letters from England, volume published in 1807 that includes two prefaces: a first one, supposedly written by the actual Spanish author of the letters, and a second one, by the so-called translator of them into English, Southey himself, who comments some of the translation strategies he has made use of. Today, it is very easy to realise that it is not a translation indeed, but a pseudo-translation, a fact that only makes the book much more attractive.
\end{abstract}

Key words: Southey, translation, pseudo-translation, English, Spanish.

\section{RESUMEN}

El escritor romántico inglés Robert Southey (1774-1843) no fue sólo un avezado traductor de clásicos medievales castellanos, sino un hábil manipulador de los sofisticados procesos culturales que comprende todo hecho traductor, como es el caso de sus Letters from England, volumen publicado en 1807 con dos prólogos. El primero de estos se supone escrito por el autor real español de las cartas, y el segundo por el traductor de las mismas al inglés, el mismo Southey en realidad, quien comenta las estrategias de traducción empleadas. Hoy en día es fácil comprender que no se trata de una traducción, sino de una pseudotraducción, lo que no hace más que añadir atractivos al libro.

Palabras clave: Southey, traducción, pseudotraducción, ingles, español.

\section{INTRODUCTION}

The name of Robert Southey (1774-1843), the devoted man of letters who produced thousands and thousands of printed pages, the versatile artist: biographer, poet, translator, 
essayist, scholar, researcher, prose writer, etc., is still mainly associated with the idyllic Lake District in England (McCracken 1985), where he finally settled down with his family, and shared his life and experiences with epoch-making poets of genius such as Coleridge (1772-1834) and Wordsworth (1770-1850), and it is not a bad point to begin with.

Besides, I must acknowledge, that the study, no matter how modest, of Southey's very complex human and literary figures, from the watchtower of this twenty-first century of ours, sometimes arouses a deep feeling of melancholy: Who cares about this man today? Who reads his books, ie, interprets his messages or benefits from his legacy? How many Spaniards, for example, know that there was a devoted friend of Spain named Robert Southey? (Chamosa 1987: 340-348). Very few indeed. Were those never-ending hours of unceasing work spent in vain? Maybe or maybe not, but, at least, these humble paragraphs of mine will strive to make a difference here for a short while.

The Southey that interests me now is the one that traveled around, admired and loved Spain and Portugal almost throughout his whole life, and their countrysides, peoples, cultures, languages and legendary literatures. And it all started by an unexpected visit in 1795:

Before his final settlement in Keswick, he spent two considerable periods with his uncle in Portugal. It was here that he developed his interest in Portuguese and Spanish history and literature, a subject he became the leading English authority. His first impressions of the country, indeed, were unfavourable (Carnall 1971: 7).

His well-to-do uncle was chaplain to the British community at Lisbon (Simmons 1951: x). His first stay in the Peninsula lasted six months (1795-1796). The results were admirable: "The Letters bear witness to the extent of his reading, in Spanish as well as in Portuguese. By the time he went home he read both languages well and spoke Portuguese fluently, if with no great accuracy and elegance" (Simmons 1945: 61). Some years later (1800-1801), he returned in company of his wife. The results then were to yield many more ripe fruits in the years to come. Apart from the many books on Portuguese and Brazilian subject matters, the Spanish collection includes the following titles:

- Letter from Spain and Portugal (1797)

- Amadis of Gaul (1803), translation

- Palmerin of England (1807), translation

- Letters from England (1807), pseudotranslation

- Chronicle of the Cid (1808), translation

- Roderick, the Last of the Goths (1914), poem

- History of the Peninsular War (1823-1832), prose

- A Tale of Paraguay (1825), poem

- The Pilgrim to Compostella (1829), poem

The old chivalric literature of Spain -Amadis of Gaul and Chronicle of the Cid, which he translated into English, was probably his favourite books in the Spanish collection. It has been said that he discovered in them an antidote to the sense of weakness which he 
found so difficult to tolerate. And that, as the Cid - the national Spanish hero- smote down his enemies, so Southey delighted to trample on his themes (Carnall 1971: 7). These books also proved the great translator Robert Southey was. His Amadis of Gaul's Preface includes sensible translation criteria or strategies such as the following: “... to have translated a closely printed folio would have been absurd ... I have reduced it to about half its length ... every part is preserved, and in the same proportions ... a modern style would have altered the character of the book, but not obsolete words ... the names which have a meaning in the original have not been translated ... I cannot be supposed that I have uniformly succeeded" (Zarandona 1992-1994: 13-14). Many theorists of the new discipline of Translation Studies will no doubt accept them willingly.

But Southey did not like everything he saw: poverty and decadence were rampant those days in the Iberian Peninsula, and the young Robert could not avoid feeling the contrast between what he saw and his own country:

Southey remained at Lisbon for three months and a half. He did not like the place at first. It was once again the filth that appalled him. "An English pigsty is cleaner than the metropolis of Portugal." "Every kind of vermin that exists to punish the nastiness and indolence of men multiplies in the heat and dirt of Lisbon." ... A terse sentence appears at the head of a letter written on $24^{\text {th }}$ February: "Lisbon, from which God grant me a speedy deliverance" (Simmons 1945: 60).

But, to his great credit, this first unfavourable impression did not prevent him from grasping the deep unique soul of the land. Besides, he was not the first English Traveller who experienced these ambivalent feelings. His Letters Written during a Short Residence in Spain and Portugal (1797), were preceded by many more very reputed eighteenthcentury travel books such as: William Dalrymple's Travels through Spain and Portugal (1777), Henry Swinburne's Travels through Spain (1779), Joseph Townsend's A Journey through Spain (1791), Arthur Young's A Tour into Spain (1793), etc. (Freixa 1993: 153154).

But, above all, he learnt from what he saw in the Peninsula to despise and hate the Roman Catholic church: monasteries, processions, images, superstitions, etc. (Simmons 1945: 61). Robert Southey was a faithful sheep of the Church of England and a man with strong religious feelings, but his deep interest in religion did not make him — to his great credit again - an absolutely prejudiced enemy of all other Christian branches. He just exhibited his preferences from time to time, and nothing prevented him from admiring everything that deserved his admiration:

Southey wrote these words while he was working on Roderick, a poem which might have come from the pen of a Catholic apologist. A Tale of Paraguay and the History of Brazil show how warmly he felt towards the Jesuits of South America ... The same is true of his attitude towards the protestant sect of the Quakers. He was united with them in steadfast opposition to slavery, in their warm but undogmatic religious feeling, in their stoic discipline of life, and their practical goodwill (Carnall 1971: 27). 
He had little good to say for the Roman Catholic Church. Still, he preferred Catholicism to the Calvinistic forms of protestantism which he knew in England, because it did more to kindle and satisfy the feelings and the imagination (Carnall 1971:7).

\section{PSEUDOTRANSLATION AND LETTERS FROM ENGLAND}

The full title of this book by Southey, published by Longman's in 1807, was Letters from England: by Don Manuel Alvarez Espriella. Translated from the Spanish. Jack Simmons, modern editor of it, states very clearly that the letters constitute a pseudotranslation: "They had not in fact been written by Espriella - there was no such person: neither had they been translated from the Spanish. Their real author was an Englishman, Robert Southey. Why did he choose to adopt this disguise? For an answer to that question one must turn first to the story of his life (Simmons 1951: ix).

About this curious phenomemon of pseudotranslation, Gideon Toury (Toury 1981: 19) (Toury 1995: 40-46) has written the following:

(1) In certain literary-cultural circumstances, there are texts which are regarded as literary translations though no genuine STs exist for them. There is no actual TT-ST relationships, and these cases are so-called pseudotranslation or fictitious translations.

(2) Many genuine translations are in that same position, their sources are unknown, so there is no real way of distinguishing between the two groups.

(3) Pseudotranslations can go on operating as translations only as long as the forgery in not found out and accepted as a literary fact in itselt.

(4) Some of the uses of pseudotranslating are closely associated with the manipulation of the text's reception by the audience:

4.1) They are a convenient way of introducing novelties into a culture, especially in cultures reluctant to deviate from sanctioned models and norms, which explains why so many innovators throughout the ages have disguised their own texts as translations.

4.2) They are convenient for an author who would not like his/her new endeavours to be associated with his/her name.

4.3) They are convenient to conquer an author's fear of censorial measures against his/ her work. The way censorship is applied to translations has often been much more lenient: non-domestic origin of translations makes them look less manacing.

(5) Not everything presented as a translation would also pass for one without arousing any real suspicion. An author wishing to become a serious pseudotranslator must invest some efforts in a way which would be sufficiently persuasive, ie, features which have come to be associated, in the target culture in question, with translation, enhancing their resemblance to genuine translations. Only authors well aware of these characteristics can imitate them.

(6) They also testify to what a society has become conscious of in its conception of translation. Texts come into being disguised as translations because there exists a notion 
of translation in a culture, and this notion and its realizations are assigned certain functions, recognized and acknowledged by its members.

(7) Consequently, a TT-oriented theory should no doubt account for them as well as for genuine translations. It does not mean that pseudotranslations must be considered central objects of Tranlation Studies, but just proper objects of the discipline, very much like normative pronouncements on translation.

\section{A PSEUDOTRANSLATOR NAMED ROBERT SOUTHEY}

\subsection{The story of a forgery}

Simmons claims that what Southey did was not an original idea. Many travellers had written descriptions of England in the eighteenth century. Daniel Defoe's Tour through the Whole Island of Great Britain, which was published in 1724-6, was one of the earliest and remained the most famous (Simmons 1951: xv-xvi). All these descriptions of England have something in common: They were written by Englishmen. Many foreign visitors wrote about England too. And the popularity of these accounts of England by foreigners led to a further development: the use of foreign name to cloak the identity of an Englishman writing about his own country. It was an old literary device, imported into England, like so much else in the late seventeenth century, from France. The same device was used, with much more sparkling effect, by Montesquieu in his first important work, the Lettres Persanes, which were published in 1721. From this prototype two English imitations followed: Horace Walpole's and Oliver Goldsmith's (Simmons 1951: xvii-xviii).

And this is what Southey did: He published under the mysterious pseudonym of Don Manuel Alvarez Espriella, probably to excite curiosity, and produced a work with no actual ST-TT relationship. In other words, a translation as long as the forgery is not found (Toury 1995: 40-52). In this case, the so-called forgery was very quickly found out.

The first 1807 edition still sold quickly. The puzzle of the book's authorship did intrigue its readers and help to advertise it (Madden 1972: 121). Before the end of 1807 Southey reported that the publishers were suggesting a reprint and, consequently, a second edition was published in 1808. Although sales declined, a third edition appeared in 1814, but this one did no sell well probably because the secret was already known. This was the last one in England during his lifetime. Southey even wanted to write a sequel, but little interest remained in a second work once Espriella's identity was disclosed (Simmons 1951: xxiii-xxiv).

\subsection{How did everyone find the forgery out so easily!}

Robert Southey could not keep the secret for a long time, which did not help him make a reputation as a brilliant pseudo-translator. He failed in realizing and adjusting his work to the poor concept of translation in his society. His contemporaries have never heard of a translation sounding like a second original. They could distinguish his original work from a real translation easily: "Paradoxically, the secret of the book is given away by its 
greatest virtue: the ease and sweetness of its style. No translation, however skilful, could run so naturally ... it has the raciness of originality, not the lees of translation" (Simmons 1951: xxii). All reviewers guessed at once that the author was an Englishman, not a Spaniard. For example, Francis Jeffrey, from the Edinburgh Review, who wrote about this in 1808, and Christopher Lake Moody, from the Monthly Review, who also did in 1808. He showed - they said - an acquaintance with England altogether too intimate for a Spaniard (Simmons 1951: xxii-xxiii). It is evident that they had never heard of the marvels of thorough documentation either. They state:

This publication appears to us to pretty evidently the work of some experienced English bookmaker... Observations on our own country by a stranger or foreigner, on the other hand, never fail to excite curiosity, and obtain at least a temporary circulation... We are anxious to know what other people say of us; and are apt to suppose, perhaps not very erroneously, that we gain a new knowledge of familiar objects, by seeing them with the eyes of a stranger. This alone would afford a sufficient temptation to the deception which has here been attempted (Jeffrey 1972: 121-122).

Whatever may have been their motive, these pseudo-Spaniards have over-acted their part, and have betrayed such an intimate acquaintance with English literature, arts, politics, and sects, as a stranger just landed on our coasts could never have attained (Moody 1972: 125)

\subsection{What were the reasons for a forgery?}

Successful or not, Southey had some reasons to do what he did: to adopt the mask of Espriella and to manipulate the reception of his text. Simmons mentions some of them (Simmons 1951: xviii-xix). Apart from the natural curiosity to know what other foreign people think of us, his biographer adds that:

- Southey loved a mystery for itself. This was not the only work he published anonymously. A large proportion of his prose writing appeared unsigned in periodicals

- He regarded his book as a potential best-seller, and he thought anonymity was its surest protection against the attacks, irrespective of its merit, by his literary enemies

The much greater latitude and freedom that a translation allowed him to discuss the more delicate subjects of politics and religion (Jeffrey 1972: 122) must also be taken into account.

But economic benefits - he was a husband and a father- were surely his most important incentive, as the writer himself wrote: "The book will be very amusing, and may very possibly pass awhile for a translation. It will certainly excite attention and curiosity, and I calculate upon greater profits than anything has ever yet brought me in" (Simmons 1951: xv). 


\subsection{The efforts invested}

Successful or not, Southey invested a lot of effort in his literary forgery. The secret of the authorship had to be guarded closely and kept up with the greatest care. Only a few of his close friends knew it, and the book was printed by Richard Taylor, whom he knew he could implicitly trust. He was also confident on his accurate knowledge of Spanish character. The fiction of the Spaniard's authorship, ie, the ideas and prejudices of a moderate Spanish Catholic, is well maintained (Simmons 1951: xxi-xxii).

But the most important effort Southey, the Great Pretender, made to make his project believable was to write the two Prefaces. A preface by the English translator (Southey 1951: 13), and a preface by the author, Don Manuel, translated from the Spanish (Southey 1951: 15-16), crowded with personal data and other facts that really make the text seem a real translation.

The following paragraphs from the Prefaces are very self-explanatory:

PREFACE BY THE TRANSLATOR (Southey 1951: 13)

The remarks of Foreign Travellers upon our own country have always been so well received by the Public, that no apology can be necessary for offering to it the present Translation.

The Author of this work seems to have enjoyed more advantages than most of his predecessors.

He boasts also of his impartiality: to this praise, in general, he is entitled.

The Translator has seldom thought it necessary to offer any comments upon the palpable errors and mis-statements which his spirit has sometimes occasioned: the few notes which he has annexed are distinguised by the letters TR.

PREFACE (by the author and translated) (Southey 1951: 15-16)

A volume of travels rarely or never, in our days, appears in Spain: in England, on the contrary, scarcely any works are so numerous.

We seldom travel; and they among us who do, never give their journals to the public. It is because literature can hardly be said to have become a trade among us, or because vanity is no part of our national character? The present work, therefore, is safe from comparison, and will have the advantage of novelty.

I went to England under circumstances unusually favourable, and remained there eighteen months, during the greater part of which I was domesticated in an English family.

In thus delineating to my countrymen the domestic character and habits of the English, and the real state of England, I have endeavoured to be strictly impartial; and, if self-judgment may in such a case be trusted, it is my belief that I have succeeded.

\section{SOME CURIOUS EXCERPTS FROM THE LETTERS}

The following brief collection of paragraphs are all very telling in themselves, but they only represent a very small amount of the possibilities of study this book by Southey treasures up. As Toury claims, pseudo-translations are also object of the field of Translation 
Studies and, consequently, of all the cultural differences involved in any translation process (Toury 1995: 40-52).

Another fact is very true: All Southey's own preferences and dislikes appear in this book, and they show complete consistency, as these fragments show as well.

\subsection{Justice}

Don Manuel feel admiration for the advanced legal system of England, one of the most important beauties of the country:

Excellent administration of Justice.... Of late years the office of jailor has become of considerable importance, and ennobled by the title of Governor. The increase of criminals has given it this consequence; and that the number of criminals must be prodigiously increased is sufficiently proved by the frequency and magnitude of these new prisons. In fact, more persons annually suffer death in the country than in the whole of Christendom besides; and from hence it is inferred, that either the people of England are the most depraved people in Europe, or their laws the bloodiest. No, say the English; the true reason is, that in other countries crimes are committed with impunity, —and they never fail to instant assassination: thus they satisfy themselves and silence the objector. True it is that in all the southern parts of Europe, to our shame be it spoken, assassination if far more frequently committed than punished: but murder with us, generally speaking, is neither in its motive nor in its manner the same atrocious crime which in England is regarded with such religious abhorrece, and punished with such certain severity (Southey 1951: 217).

\subsection{Public Services}

The cathedrals of Spain are more imposing, but dirt is exceptional in English cities:

Exeter is an ancient city, and has been so slow in adopting modern improvements that it has the unsavoury odour of Lisbon ... The cathedral is a fine object ... It cannot be compared with Seville, or Cordova, or Burgos; yet certainly it is a noble pile (Southey 1951: 27).

\subsection{Catholicism}

Álvarez Espriella cannot help feeling sad about the lost Catholic past of England, and Southey lets him go freely:

At the north side is a small but beautiful ruin of a chapel once belonging to a brotherhood of the Holy Ghost. J__ led me to see it as a beautiful object, in which light only all Englishmen regard such monuments of the piety of their forefathers and of their own lamentable apostasy. The roof had once been adorned with the history of the prophets and the holy apostles; but the more beautiful and more celebrated these decorations, the more zealous were they destroyed in the schism. I felt deeply the profanation, and said a prayer in silence upon the spot where the altar should have stood (Southey 1951: 42). 
To a modern reader the one fault of the Letters is that they contain too much about religion. But it is a unavoidable fact that Southey was himself genuinely interested in the subject (Simmons 1951: xix-xxi).

\subsection{Trade}

England is a businesslike country of traders and merchants, and the Spaniard admits their superior material well-being without doubt:

The oddest thing which I saw in the whole walk were a pair of shoes in one window floating in a vessel of water, to show that they were water-proof; and a well-dressed leg in another, betokening that legs were made there to the life. One purchase I ventured to make, that of a travelling caissette; there were many at the shop-door, with the prices marked upon them, so that I did not fear imposition. These things are admirably made and exceedingly convenient (Southey 1951: 54) ... imposing splendour of the shops (Southey 1951: 68).

\subsection{Chimney-Sweepers}

Only a few years before, William Blake (1757-1827) in his Songs of Experience (1794) had publicly denounced the shameful abuse of children in England, mainly of little chimney-sweepers. Not everything is beautiful in the country, and Espriella notices it as well:

Yesterday, I was amused by a spectacle which you will think better adapted to wild African negroes than to so refined a people as the English. Three or four boys of different ages were dancing in the street; their clothes seemed as if they had been dragged through the chimney, as indeed had been the case (Southey 1951: 78).

Southey's contemporaries understood the message:

Naturally disposed to consider our country as the best of all possible countries, we do not sufficiently criticize our characteristic traits and numerous defects; and while our travellers amuse us with the absurdities of foreign nations, we are not aware that we ourselves, on many accounts, are open to satirical animadversion (Moody 1972: 125).

\subsection{English Houses}

Comfort is a long-established tradition in England houses:

An Englishman delights to show his wealth; every thing in his house, therefore, is expensive: a whole dwelling in our country is furnished at less cost than is bestowed here upon a single apartment (Southey 1951: 81). 


\subsection{The Bible}

The Catholic visitor is made to feel sympathy for the popular use of the Bible in Protestant countries such as England:

Opinion that the domestic Use of the Scriptures would not be injurious in Spain. ... But in all ranks of society there are numbers of persons to whom the perusal of God's own word is an inestimable comfort. No book of devotion would so certainly fix their attention; ... It is a pleasure to them, as well as a consolation (Southey 1951: 335).

\subsection{The Spanish Empire}

Don Manuel, on the contrary, does not hesitate to defend Spain and its glorious deeds in America from the so-called Black Legend:

They do not know that after having destroyed the bloody and execrable idolatry of the American Indians, we imparted to them our arts, our language, and our religion; and that the spiritual conquests of our missionaries were not less rapid, nor less extraordinary, than the victories of Cortes and Pizarro ... It amuses me to hear these people talk of their West Indian possessions. England has as great an idea of her own importance and power, as a one-eyed man has of the magnitude of his nose, when the candle is on his blind side (Southey 1951: 407).

\subsection{The merry Spain}

He also promotes the modern myth of a merry Spain, myth still alive nowadays, and probably a very true one:

Spanish gravity is the jest of this people. Whenever they introduce a Spaniard upon the stage, it is to ridicule him for his pride, his jealously, and his mustachios. According to their notions, all our women who are not locked up in convents, are locked up at home; guarded by duennas as vigilant as dragons, and husbands, every one of whom is as fierce as the Grand Turk. They believe also, that a Spaniard thinks it beneath his dignity ever to laugh, except when he is reading Don Quixote; then, indeed, his muscles are permitted to relax.

I am writing upon Sunday evening, at the hour when in our cities the people are at the theatre of the bull-fight, when in every street and village the young are dancing with their castanets, and at every door you hear the viola. What is the scene in England at this time? All public amusements are prohibited by the daemon of Calvinism (Southey 1951: 411).

\section{CONCLUSIONS}

5.1.- Gideon Toury claims that there is no real difference between a translated target text whose source text is unknown and a pseudotranslation that has not been found out yet (Toury 1995: 40-52). In the first place, I would like to add that there is no such thing as a perfect pseudotranslation: at least one individual knows that it is a pseudotranslation: the 
faker or pseudotranslator. Southey told his plans only to a very small number of close friends and relatives, and to his editor (he wanted the money). They knew as well. For them, the aforementioned claim does not work either. Secondly, it is also true that people read translated books everyday without realizing that they are reading a translation. This fact does not turn those books or texts into pseudotranslations.

Besides, Southey was very quickly found out by his contemporaries, who knew it was not a translation. It also makes sense to think that generally pseudotranslations - many of them very famous, Don Quixote, for example — are all very quickly found out. Maybe there are some or many books that are successful pseudotranslations, but, although more research is needed, it makes sense to think that the reason why it is very unlikely to have a almost perfect 'fictitious translation' lies in the fact that a pseudotranslation that has not been found out, if such a thing exists, is not the same as a translated text whose source text is unknown, because it is not really a translation. We all know that right now prestigious translation specialists such as Mona Baker, from the University of Manchester, are trying to prove that the linguistic features of English original and translated texts are different, and they are doing it with the help of huge corpora.

5.2.- Nord (1997: 53-79) explains that translation is an 'Interpersonal Interaction' in which the people involved play different roles. The most sophisticated version of this analysis, the one in which each step is played by a different individual or group of individuals, consists of roles such as: initiator, commissioner, translator, source text sender, source text producer, target text addressee, target text receiver, target text user. Pseudotranslations, as translations, not only can exemplify a system like this for those who do not know, but a completely different one for those who do, or, even, a much more sophisticated one that joins both, which, of course, opens many challenging research channels and justifies their inclusion into the field of Translation Studies again.

5.3.- Nord (1997: 39-52) also proposes a 'Translation-Oriented Model of Text Functions' consisting of four main functions. The Letters by Espriella/Southey are very informative (referential function), they tell us many things about England and Spain. They are also very expressive: nationalism, religion, personal feelings; they are very evaluative as well: this is better, this is worse. But the fact that they are a pseudotranslation makes the appelative function — sender's oriented — probably the most important one. The interest in manipulating the audience it order to make certain purposes possible is very clear in Southey as it has been studied before. Maybe, this is another characteristic of pseudotranslations that makes a difference between this text type and real translated texts whose source texts are unknown.

\section{REFERENCES}

CARnall, G. 1971. Robert Southey. Writers and their Work. London: Longman.

Chamosa González, J. L. y T. Guzmán González. 1987. "Robert Southey, traductor de poesía española". Actas de las I Jornadas Nacionales de Historia de la Traducción. León: Universidad de León, 340-348. 
FreiXa, C. 1993. Los ingleses y el arte de viajar. Barcelona: Ediciones del Serbal.

JEFFrey, F. 1972. "Review on 'Letters from England"”. Robert Southey. The Critical Heritage. Ed. L. MaIDEN. London and Boston: Routledge and Kegan Paul, 121-124.

Madden, L., ed. 1972. Robert Southey. The Critical Heritage. London and Boston: Routledge \& Kegan Paul.

McCRACKen, D. 1985. Wordsworth and the Lake District. Oxford: O.U.P.

Moody, C. L. 1972. "Review on 'Letters from England"'. Robert Southey. The Critical Heritage. Ed. L. MAIDEN. London and Boston: Routledge and Kegan Paul, 124-126.

Nord, C. 1997. Translating as a Purposeful Activity. Manchester: St. Jerome.

Simmons, J. 1945. Southey. London: Collins. Press, ix.xxvi.

1951. “Editor's Introduction”. Letters from England. London: The Cresset

Southey, R. 1951. Letters from England. Ed. J. Simmons. London: The Cresset Press.

Toury, G. 1981. “Translated Literature: System, Norm, Performance”. Poetics Today, Vol. 2/4: 9-27.

1995. "Pseudotranslations and Their Significance". Descriptive Translation Studies and Beyond. Amsterdam and Philadelphia: John Benjamins, 40-52.

Zarandona, J. M. 1992-1994. "Robert Southey: Hispanista y traductor de obras clásicas castellanas medievales". Revista de Investigación. XII / 1: 7-27. 